\title{
Urgences
}

\section{La symbiose d'Antiope et de son satyre}

\section{Danielle Saint-Cyr}

Numéro 13, mars 1986

Éclats d'atelier

URI : https://id.erudit.org/iderudit/025238ar

DOI : https://doi.org/10.7202/025238ar

Aller au sommaire du numéro

Éditeur(s)

Urgences

ISSN

0226-9554 (imprimé)

1927-3924 (numérique)

Découvrir la revue

Citer ce document

Saint-Cyr, D. (1986). La symbiose d'Antiope et de son satyre. Urgences, (13),

83-83. https://doi.org/10.7202/025238ar d'utilisation que vous pouvez consulter en ligne.

https://apropos.erudit.org/fr/usagers/politique-dutilisation/ 


\section{LA SYMBIOSE D'ANTIOPE ET DE SON SATYRE Danielle Saint-Cyr}

I'aube, I'horizon blanchi, les sables chauds en décembre, les utopies sondées, telle Antiope séduite par Zeus, le corps nu offert aux divinités célestes, le désir olympien de voluptés épicuriennes du satyre, les fruits de la vigne offerte et l'amante qui les palpe, les soupèse et les presse jusqu'à en extirper les moindres délices, la mer monte, les vents chauds soufflent, caressent les monts callipygiens, il explore ses jardins profonds, plonge au sein de son image, elle entend les bruits sourds de la tempête qui monte en lui, s'approchent et s'éloignent, la douce brise d'une haleine dans ses cheveux ambrés, le tangage des désirs ascendants et descendants, le roulis d'une vague qui la couvre et la découvre, le tronc de l'enchanteresse roule sur lui-même, poussé par le ressac de celui qui I'habite, les avant-bras en appui, en position du pavot, le bassin d'eau sucrée et veloutée où une actinie pourprée, avide devant l'attente insupportable, saisit enfin sa proie, la serre, l'étouffe tandis que germe l'ouragan dans l'iris livide de l'amant qui, lui, contemple dans celui de sa maîtresse la fiévreuse appétence d'une libido assouvie, les parfums de musc exhalent des effluves odoriférants, les amants se livrent leurs richesses intimes et, du plus profond de leurs abîmes, l'orage éclate cinglant et grandiose tandis qu'ils lui lancent leurs plaintes sauvages, l'écume mousseuse d'un fleuve coule dans le sein de la sirène, mille petites rivières blanches se meurent sur les sables chauds, une lumière brillante et rosée colore d'une douceur exquise les déités enlacées, tel un prisme leurs regards miroitent les teintes rosées de l'aurore 